\title{
Ehrlichia canis detection in dogs from Várzea Grande: a comparative analysis of blood and bone marrow samples
}

\author{
Deteç̧ão de Ehrlichia canis em cães domiciliados em Várzea Grande: \\ análise comparativa entre amostras de sangue e medula óssea \\ Herica Makino ${ }^{\mathrm{I}}$ Valéria Régia Franco Sousa ${ }^{\mathrm{II}}$ Mahyumi Fujimori ${ }^{\mathrm{II}}$ \\ Juliana Yuki Rodrigues ${ }^{\text {III }}$ Alvaro Felipe Lima Ruy Dias ${ }^{I}$ Valéria Dutra ${ }^{\text {II }}$ \\ Luciano NakazatoII Arleana do Bom Parto Ferreira de Almeida ${ }^{I^{* *}}$
}

ABSTRACT

The objective of this study was to compare the DNA detection of Ehrlichia canis in blood and bone marrow to determine the prevalence of the agent in Várzea Grande, Mato Grosso. Blood samples and bone marrow from 80 dogs of both sexes, different breeds and age, were collected and processed for a cross-sectional study performed using nested PCR. Of the $80 \mathrm{dogs}$, $61(76.3 \%)$ had $\boldsymbol{E}$. canis DNA in one of the samples. The buffy coat was positive in $42 \mathrm{dogs}(52.5 \%)$ and the bone marrow was positive in 33 (41.3\%). There was no significant association between the positive biological samples of either the buffy coat or bone marrow and the presence or absence of clinical signs $(P=0.49)$. No risk factor was associated with infection in the studied area. The bone marrow samples were efficient for the molecular diagnosis of canine ehrlichiosis, particularly when there was a negative blood sample, although infection was present.

Key words: canine ehrlichiosis, diagnosis, nested PCR, biological samples.

RESUMO

Este trabalho teve por objetivo comparar a detecção de DNA de Ehrlichia canis em amostras de sangue e medula óssea, além de determinar a ocorrência do agente em Várzea Grande, Mato Grosso. Amostras de sangue e medula óssea de 80 cães, de ambos os sexos, diferentes raças e idade, foram coletados em estudo seccional e processados para realização de nested PCR. Dos 80 cães, 61 (76,3\%) apresentaram DNA de $\boldsymbol{E}$. canis em uma das amostras pesquisadas. A capa leucocitária foi positiva em 42 (52,5\%) e a medula óssea em 33 (41,3\%). Não foi observada associação significativa com a positividade das amostras biológicas, sangue ou medula óssea, e a presença ou ausência de sinais clínicos $(P=0,49)$. Nenhum fator de risco foi associado à infecção na área pesquisada. A amostra de medula óssea mostrou-se bom sítio para o diagnóstico molecular da erliquiose canina, principalmente quando da infecção com negatividade da amostra sanguínea.

Palavras-chave: erliquiose canina, diagnóstico, nested PCR, amostra biológica.

\section{INTRODUCTION}

Ehrlichia canis, the etiological agent of canine monocytic ehrlichiosis (CME), is a bacteria distributed worldwide that may cause lethal disease in dogs (AGUIAR et al., 2015). The pathogenesis of the disease involves an incubation period of 8 to 20 days, followed by an acute, subclinical and sometimes chronic phase (HARRUS \& WNER, 2011). Normally, during the acute phase, infected dogs recover spontaneously. However, when they enter the subclinical stage, the dogs remain infected for longer periods. At this stage, dogs do not eliminate the agent from the body, and they develop the chronic phase of the disease, characterised by bone marrow suppression and bleeding, followed by death (WANER \& HARRUS, 2013).

Because the clinical signs associated with the disease are nonspecific, clinical diagnosis is difficult. Therefore, a laboratory diagnosis of infections caused by $\boldsymbol{E}$. canis morulae is performed using the visualisation of mononuclear cells, the detection of

'Programa de Pós-graduação em Ciências Veterinárias, Universidade Federal de Mato Grosso (UFMT), Cuiabá, MT, Brasil.

${ }^{I I}$ Departamento de Clínica Médica Veterinária, Faculdade de Agronomia, Medicina Veterinária e Zootecnia, UFMT, Av. Fernando Correa da Costa, 2367, Boa Esperança, 78060-900, Cuiabá, MT, Brasil. E-mail: arleferreira@gmail.com. "Corresponding author.

IIIMédica Veterinária Autônoma, Cuiabá, MT, Brasil. 
antibodies using serological techniques and molecular analysis using PCR (TANIKAWA et al., 2013).

The introduction of molecular techniques for the detection of $\boldsymbol{E}$. canis has allowed for the rapid, sensitive and specific diagnosis of acute and chronic phases of the disease. Various PCR techniques can be used, such as nested PCR (OLIVEIRA et al., 2009), RFLP-PCR (restriction fragment length polymorphism) and real-time PCR (BANETH et al., 2009). Several target genes, including p28, p30, dsb, and VirB9, and PCR for the 16S rRNA gene and p30 are the most commonly used targets (HARRUS \& WANER, 2011). Different biological sites can also be used (WANER \& HARRUS, 2013). Animal health and CME is of global importance. The objective of this study was to compare the presence of $\boldsymbol{E}$. canis DNA in the blood and bone marrow of dogs, as well as to determine the occurrence of $\boldsymbol{E}$. canis in Várzea Grande, Mato Grosso.

\section{MATERIALS AND METHODS}

Animals and study area

Dogs in this study were obtained from a cross-sectional study for canine visceral leishmaniasis in the municipality of Várzea Grande, Mato Grosso, the neighbourhoods of São Matheus, Jardim Eldorado and

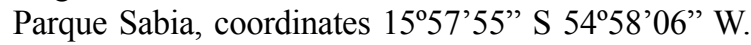
The survey was conducted by home visits, considering one residence for every five, totalling 521 dogs. The bone marrow was obtained from approximately $10 \%$ of the population studied. Dogs of all ages, both sexes and different breeds were included in this study with prior permission of the owner. The dogs were clinically evaluated for the presence of clinical signs of infection with $\boldsymbol{E}$. canis, such as apathy, anorexia, weight loss, lymphadenopathy, hepatomegaly, splenomegaly and ophthalmopathy and the clinical and epidemiological characteristics of the registered disease.

With the consent of the owners, the dogs were mechanically restrained and underwent sedation with ketamine hydrochloride $\left(10 \mathrm{mg} \mathrm{kg}^{-1}\right)$ and acepromazine $\left(0.2 \mathrm{mg} \mathrm{kg}^{1}\right)$. Approximately $5 \mathrm{ml}$ blood was collected by cephalic or jugular puncture into tubes containing anticoagulant for the recovery of the buffy coat by centrifugation. Bone marrow samples $(0.5 \mathrm{~mL})$ were obtained via aspiration of the sternum manubrium and were stored in microtubes containing anticoagulant after prior asepsis and local anaesthesia. The biological specimens were stored at $-20^{\circ}$ until use.

\section{DNA extraction and PCR}

Extraction of DNA samples was performed using phenol/chloroform/isoamyl alcohol according to GOMES et al. (2007). E. canis DNA detection was performed using nested PCR. The primers used for the first amplification step were as follows: ECC (5'-AGAACGAACGCTGGCGGCAAGC-3') and ECB (5'-3'CGTATTACCGCGGCTGCTGGCA-3'). Primers for the second stage were ECAN (5'-CAATTATTTATAGCCTCTGGCTATAGGA-3') and HE3(5'-TATAGGTACCGTCATTATCTTCCCTAT-3'). These primers amplify fragments of 458 and 398 $\mathrm{bp}$, respectively, of the 16S rRNA gene (MURPHY et al., 1998). Positive control was (dog 3577) an animal positive for $\boldsymbol{E}$. canis, and a negative control (DNA-free reaction) was also included in all PCR experiments. Amplified products were fractionated by agarose gel electrophoresis, stained with $1.5 \%$ gel Red and visualised transilluminator (UV-300 nm). To verify that no Leishmania DNA was amplified, the primers used were tested using the DNA reference strain L. (L.) infantum (MHOM/BR/1974/PP75), and no nonspecific amplification was observed. To confirm the species, eight $(10 \%)$ samples were sequenced at the Sanger Sequencing facility (Applied Biosystems $^{\circledR}$ Genetic Analysis, Foster City, CA) according to the manufacturer's recommendations.

\section{Statistical analysis}

Data were transferred to a database and analysed with the software Epi Info 3.3.2 (CDC, Atlanta, GA, USA) using Fisher's exact or chi-square tests to assess the association between independent variables, the presence of $\boldsymbol{E}$. canis DNA positive results, the differences in the frequency for each clinical sample and the comparison of the clinical status of dogs at the $5 \%$ significance level.

\section{RESULTS}

Of the 80 dogs surveyed, 61 (76.3\%) had E. canis DNA in one of the surveyed samples. No association was observed between gender, age, race, origin of dogs, free access to the street, or the presence of ticks (Table 1). In the analysis of biological samples, the buffy coat were positive in $42(52.5 \%)$ and the bone marrow was positive in $33(41.3 \%)$ of 80 dogs. Of the positive dogs, 14 (17.5\%) showed DNA amplification of $\boldsymbol{E}$. canis in both samples. The PCR products of eight dogs $(10 \%)$ were sequenced, resulting in DNA sequences $100 \%$ identical to the sequences of $\boldsymbol{E}$. canis in GenBank (accession numbers KP844663.1, KJ995842.1, KF972452.1, and JX118827.1).

Of all the dogs, $29 \quad(36.3 \%)$ were asymptomatic, and $51(63.8 \%)$ showed some clinical signs consistent with infection by $\boldsymbol{E}$. canis, of which, $21(72.4 \%)$ and $40(78.4 \%)$, respectively, were positive by $\mathrm{PCR}$, with no statistically significant difference $(\mathrm{P}=0.73)$. The primary clinical signs 
Table 1 - Epidemiological factors associated with positive PCR for Ehrlichia canis in a population of pet dogs in Várzea Grande, Mato Grosso.

\begin{tabular}{|c|c|c|c|c|}
\hline \multirow{2}{*}{ Variables } & \multicolumn{2}{|c|}{---------Dogs-------- } & \multicolumn{2}{|c|}{ Análise Univariada } \\
\hline & Total & Positive (\%) & $P$ & OR (CI95\%) \\
\hline \multicolumn{5}{|l|}{ Gender } \\
\hline Male & 46 & $37(80.4 \%)$ & \multirow[t]{2}{*}{0.30} & \multirow{2}{*}{$\begin{array}{l}0.58 \\
(0.18-1.75)\end{array}$} \\
\hline Female & 34 & $24(70.6 \%)$ & & \\
\hline \multicolumn{5}{|l|}{ Breed } \\
\hline SRD ${ }^{*}$ & 76 & $58(76.3 \%)$ & \multirow[t]{2}{*}{0.67} & \multirow{2}{*}{$\begin{array}{l}0.93 \\
(0.10-2.11)\end{array}$} \\
\hline $\mathrm{CRD}^{*}$ & 04 & $03(75 \%)$ & & \\
\hline \multicolumn{5}{|c|}{ Age groups (year) } \\
\hline Indefinite age & 18 & $15(83.3 \%)$ & \multirow{5}{*}{0.35} & \multirow{5}{*}{----- } \\
\hline$<1$ & 10 & $06(60 \%)$ & & \\
\hline $1-3$ & 17 & $15(88.2 \%)$ & & \\
\hline $3-6$ & 21 & $16(76.2 \%)$ & & \\
\hline$>6$ & 14 & $9(64.3 \%)$ & & \\
\hline \multicolumn{5}{|c|}{ Access to the street } \\
\hline Yes & 33 & $24(72.7 \%)$ & \multirow{2}{*}{0.53} & \multirow{2}{*}{$\begin{array}{l}0.72 \\
(0.23-2.06)\end{array}$} \\
\hline No & 47 & $37(78.7 \%)$ & & \\
\hline \multicolumn{5}{|l|}{ Ticks } \\
\hline Yes & 41 & $30(73.2 \%)$ & \multirow{2}{*}{0.50} & \multirow{2}{*}{$\begin{array}{l}0.70 \\
(0.22-1.91)\end{array}$} \\
\hline No & 39 & $31(79.5 \%)$ & & \\
\hline
\end{tabular}

*SRD - Without defined Race; *CRD - With defined Race.

observed were apathy, weight loss, lymphadenopathy, splenomegaly, hepatomegaly and ophthalmopathies.

For clinical the presence or absence of clinical signs, there was no significant association between the positivity of the biological samples, buffy coat and bone marrow (Table 2). There was no significant association between the two types of biological samples within the asymptomatic dog group $(\mathrm{P}=0.24)$ and symptomatic group $(\mathrm{P}=0.49)$.

\section{DISCUSSION}

The high incidence of infection with E. canis found in this study is consistent with data obtained in different regions of Brazil (DAGNONE et al., 2009; TANIKAWA et al., 2013) and Mato Grosso (MELO et al., 2011) based on serological analysis. In this study, nested PCR of buffy coat and bone marrow samples showed an occurrence of infection in $76 \%$ of dogs. This finding differs from that of WITTER et al. (2013), who analysed buffy coat samples and observed $\boldsymbol{E}$. canis infection in $23.3 \%$ of dogs. The high occurrence can be related using two sites where bacteraemia is observed during different stages of the disease (MILONAKIS et al., 2003).

Direct exposure to the vector tick, $\boldsymbol{R}$. sanguineus (CARLOS et al., 2011) and age (COSTA JUNIOR et al., 2007) were considered risk factors for infection with $\boldsymbol{E}$. canis in other regions; however, these factors were not associated with infection in the dogs surveyed, as described by SILVA et al. (2012).

In epidemiological analyses, the blood sample is easily obtainable and provides good results (SILVA et al., 2012; SANTOS et al., 2013). However, the detection of the agent can decrease at this site with the progression of infection or the treatment of bacteraemia compared to other sites (HARRUS et al., 2004; BANETH et al., 2009). In this study, the highest percentage of DNA amplification in buffy coat indicates acute infection as demonstrated by BANETH et al. (2009), who analysed an experimental infection with $\boldsymbol{E}$. canis in dogs in blood and spleen. However, determining the stage of infection in dogs naturally infected with canine ehrlichiosis is difficult because of the possible presence of similar acute and chronic infection clinical signs (HARRUS \& WANER, 2011).

The absence of apparent clinical signs and the long duration of the subclinical stage may hinder the detection of infection (HARRUS \& WANER, 2011; WANER \& HARRUS, 2013), likely represented in this study by the asymptomatic group. HARRUS et al. (1998) observed the increased detection of $\boldsymbol{E}$. canis in spleen samples in the subclinical stage, and in blood and bone marrow in the acute phase, whereas the number of positive animals detected by PCR using blood and spleen samples was similar (HARRUS et al., 2004). However, spleen samples are not routinely

Table 2 - DNA detection of $\boldsymbol{E}$. canis using nested PCR in the buffy coat and bone marrow compared to clinical signs observed in dogs in Várzea Grande, Mato Grosso.

\begin{tabular}{|c|c|c|c|c|c|c|}
\hline Clinic Analysis & $\begin{array}{c}\text { Negative } \\
+/(\%)\end{array}$ & $\begin{array}{c}\text { Buffy Coat } \\
+/(\%)\end{array}$ & $\begin{array}{l}\text { Bone Marrow } \\
\quad+/(\%)\end{array}$ & $\begin{array}{c}\text { Both } \\
+/(\%)\end{array}$ & $x^{2}$ & $\mathrm{P}$ \\
\hline Asymptomatic & $8(10)$ & $12(15)$ & $6(7.5)$ & $3(3.8)$ & 2.42 & 0.49 \\
\hline Symptomatic & $11(13.8)$ & $16(20)$ & $13(16.3)$ & $11(13.8)$ & & \\
\hline Total & $19(23.7)$ & $28(35)$ & $19(23.7)$ & $14(17.5)$ & & \\
\hline
\end{tabular}


used in clinical practice because obtaining the samples is invasive (BANETH et al., 2009).

MYLONAKIS et al. (2004) and SIARKOU et al. (2007) detected $\boldsymbol{E}$. canis DNA in bone marrow samples of $68.42 \%$ and $75 \%$ of surveyed dogs, respectively, during the chronic phase of infection. Despite no association between clinical signs and samples, there was a higher rate of observation of E. canis DNA in blood samples, independent of the analysed group. However, MOREIRA et al. (2005) identified a greater number of developmental forms of $\boldsymbol{E}$. canis in the bone marrow compared to dog blood during the acute phase of the disease. MYLONAKIS et al. (2003) reported the occurrence of $\boldsymbol{E}$. canis sequestration in the spleen during the subclinical stage and chronic disease as well as in the bone marrow during the chronic phase.

\section{CONCLUSION}

Infection with $\boldsymbol{E}$. canis is highly prevalent in dogs in the city of Várzea Grande, Mato Grosso, and bone marrow is a good site for the molecular diagnosis of canine ehrlichiosis, particularly when infection is suspected despite of negative blood sample.

\section{ACKNOWLEDGEMENTS}

The Coordenação de Aperfeiçoamento de Pessoal de Nível Superior (CAPES) Brasil, AUXPE n $3531 / 2014$, for financial support.

\section{BIOETHICS AND BIOSSECURITY COMMITTEE APPROVAL}

The Ethics Committee on Animal Use approved this study (CEUA - UFMT) Protocol 23108.018081/12-0.

\section{REFERENCES}

AGUIAR, D.M.; MELO, A.L. Divergence of the TRP36 protein (gp36) in Ehrlichia canis strains found in Brazil. Ticks and Tickborne Diseases, n.6, p.103-105, 2015. Available from: <http:// www.sciencedirect.com/science/article/pii/S1877959X14001952>. Accessed: Dec. 20, 2014. doi: 10.1016/j.ttbdis.2014.10.003.

BANETH, G. et al. Longitudinal quantification of Ehrlichia canis in experimental infection with comparison to natural infection. Veterinary Microbiology, n.136, p.321-325, 2009. Available from: <http://www. sciencedirect.com/science/article/pii/S0378113508005488>. Accessed: Nov. 17, 2014. doi: 10.1016/j.vetmic.2008.11.022.

CARLOS, R.S.A. et al. Risk factors and clinical disorders of canine ehrlichiosis in the South of Bahia, Brazil. Revista Brasileira de Parasitologia Veterinária, v.16, p.210-214, 2011. Available from: <http://www.scielo.br/scielo.php?pid=S198429612011000300006\&script $=$ sci_arttext $>$. Accessed: Nov. 17, 2014. doi: 10.1590/S1984-29612011000300006.
COSTA JR, L.M. et al. Sero-prevalence and risk indicators for canine ehrlichiosis in three rural areas of Brazil. Veterinary Journal, v.174, n.3, p.673-676, 2007. Available from: <http:// www.sciencedirect.com/science/article/pii/S1090023306002413>. Accessed: Nov. 17, 2014. doi: 10.1016/j.tvj1.2006.11.002.

DAGNONE A.S. et al. Molecular diagnosis of Anaplasmataceae organisms in dogs with clinical and microscopical signs of ehrlichiosis. Revista Brasileira de Parasitologia Veterinária, v.18, n.4, p.20-25, 2009. Available from: <http://www.scielo.br/ scielo.php?script=sci_arttext\&pid=S1984-29612009000400004 $>$. Accessed: Nov. 17, 2014. doi: 10.4322/rbpv.01804004.

GOMES, A.H.S. et al. PCR identification of Leishmania in diagnosis and control of canine leishmaniasis. Veterinary Parasitology, n.144, p.234-241, 2007. Available from: <http:// www.sciencedirect.com/science/article/pii/S0304401706006030>. Accessed: Nov. 17, 2014. doi: 10.1016/j.vetpar.2006.10.008.

HARRUS, S. etal.Investigation of splenic functions incaninemonocytic ehrlichiosis. Veterinary Immunology and Immunopathology, v.62, p.15-27, 1998. Available from: <http://www.sciencedirect.com/ science/article/pii/S016524279700127X?np=y>. Accessed: Nov. 17, 2014. doi: 10.1016/S0165-2427(97)00127-X.

HARRUS, S. et al. Comparison of simultaneous splenic sample PCR with blood sample PCR for diagnosis and treatment of experimental Ehrlichia canis infection. Antimicrobial agents and chemoteraphy, v.48, n.11, p. 4488-4490, 2004. Available from: <http://aac.asm.org/content/48/11/4488.short>. Accessed: Nov. 17, 2014. doi: 10.1128/AAC.48.11.4488-4490.2004.

HARRUS, S.; WANER, T. Diagnosis of canine monocytotropic ehrlichiosis (Ehrlichia -canis): An overview. Veterinary Journal, n.187, p.292-296, 2011. Available from: <http://www.sciencedirect. com/science/article/pii/S1090023310000353>. Accessed: Nov. 17, 2014. doi: $10.1016 /$ j.tvj1.2010.02.001.

MELO, A.L.T. et al. Seroprevalence and risk factors to Ehrlichia spp. and Rickettsia spp. in dogs from the Pantanal Region of Mato Grosso State, Brazil. Ticks and Tick-borne Diseases n.2, p.213-218, 2011. Available from: <http:/www.sciencedirect.com/ science/article/pii/S1877959X11000689>. Accessed: Nov. 17, 2014. doi: 10.1016/j.ttbdis.2011.09.007.

MOREIRA, S.M. et al. Detection of Ehrlichia canis in bone marrow aspirates of experimentally infected dogs. Ciência Rural, v.35, n.4, p.958-960, 2005. Available from: <http://www.scielo. br/scielo.php?pid $=$ S0103-84782005000400038\&script $=$ sci arttext\&tlng=es>. Accessed: Nov. 17, 2014. doi: 10.1590/S010384782005000400038 .

MYLONAKIS, M.E. et al. Evaluation of cytology in the diagnosis of acute canine monocytic ehrlichiosis: a comparison between five methods. Veterinary Microbiology, v.91, n.2, p.197-204, 2003. Available from: $<$ http://www.sciencedirect.com/science/article/pii/ S0378113502002985>. Accessed: Nov. 17, 2014. doi: 10.1016/ S0378-1135(02)00298-5.

MYLONAKIS, M.E. et al. Chronic canine ehrlichiosis (Ehrlichia canis): a retrospective study of 19 natural cases. Journal of the American Animal Hospital Association, n.40, p.174-184, 2004. Available from: http://www.ncbi.nlm.nih.gov/pubmed/15131097>. Accessed: Nov. 17, 2014. doi: 10.5326/0400174. 
SANTOS, L.G.F.D. et al. Molecular detection of Ehrlichia canis in dogs from the Pantanal of Mato Grosso State, Brazil. Revista Brasileira de Parasitologia Veterinária, v.22,n.1,p.114-118, 2013. Available from: <http://www.scielo.br/scielo.php?pid=S198429612013000100114\&script=sci_arttext $>$. Accessed: Nov. 17, 2014. doi: 10.1590/S1984-29612013005000013.

MURPHY, G.L. et al. Molecular and serologic survey of Ehrlichia canis, Ehrlichia chaffeensis, and $\boldsymbol{E}$. ewingii in dogs and ticks from Oklahoma. Veterinary Parasitology, v.79, p.325-339, 1998. Available from: <http:/www.sciencedirect.com/science/article/pii/ S0304401798001794>. Accessed: Nov. 17, 2014. doi: 10.1016/ S0304-4017(98)00179-4.

OLIVEIRA L. et al. First report of Ehrlichia ewingii detected by molecular investigation in dogs from Brazil. Clinical Microbiology Infection, n.15, p.55-56, 2009. Available from: $<$ http://onlinelibrary wiley.com/doi/10.1111/j.1469-0691.2008.02635.x/epdf>. Accessed: Nov. 17, 2014. doi: 10.1111/j.1469-0691.2008.02635.x.

SIARKOU, V.I. et al. Sequence and phylogenetic analysis of the 16S rRNA gene of Ehrlichia canis strains in dogs with clinical monocytic ehrlichiosis. Veterinary Microbiology, n.125, p.304 312, 2007. Available from: <http://www.sciencedirect.com/ science/article/pii/S0378113507002684>. Accessed: Nov. 17, 2014. doi: 10.1016/j.vetmic.2007.05.021.
SILVA, G.C.F. et al. Occurrence of Ehrlichia canis and Anaplasma platys in household dogs from northern Parana. Revista Brasileira de Parasitologia Veterinária, v.21, n.4, p.379-385, 2012. Available from: <http://www.scielo.br/scielo. php?script $=$ sci_arttext\&pid=S1984-29612012005000009\&lng= en\&nrm=iso\&tlng=en>. Accessed: Nov. 17, 2014. doi: 10.1590/ S1984-29612012005000009.

TANIKAWA, A. et al. Ehrlichia canis in dogs in a semiarid region of Northeastern Brazil: Serology, molecular detection and associated factors. Research in Veterinary Science, n.94, p.474-477, 2013. Available from: <http:/www.ncbi.nlm.nih.gov/pubmed/23141416>. Accessed: Nov. 17, 2014. doi: 10.1016/j.rvsc.2012.10.007.

WANER, T.; HARRUS, S. Canine monocytic ehrlichiosis-from pathology to clinical manifestations. Israel Journal of Veterinary Medicine, v.68, p.1, 2013. Available from: <http://www.ijvm. org.il/sites/default/files/canine_mononocytic_ehrlichiosis.pdf $>$. Accessed: Jan. 22, 2015.

WITTER, R. et al. Prevalência da erliquiose monocítica canina e anaplasmose trombocítica em cães suspeitos de hemoparasitose em Cuiabá, Mato Grosso. Semina:CiênciasAgrárias, v.34,n.6,p.38113822, 2013. Available from: <http://www.uel.br/revistas/uel/index. php/semagrarias/article/view/14804/pdf_166>. Accessed: Jan. 22, 2015. doi: 10.5433/1679-0359.2013v34n6Sup12p3811. 